\title{
RETINOIDS, REXINOIDS AND THEIR COGNATE NUCLEAR RECEPTORS: CHARACTER AND THEIR ROLE IN CHEMOPREVENTION OF SELECTED MALIGNANT DISEASES
}

\author{
Julius Brtko \\ Institute of Experimental Endocrinology, Slovak Academy of Sciences, Laboratory of Molecular Endocrinology, Bratislava, \\ Slovak Republic \\ e-mail: julius.brtko@savba.sk
}

Received: September 25, 2007; Accepted: October 8, 2007

Key words: Retinoids/Nuclear receptors/Ligand inducible transcription factors/Cancer chemoprevention/Tumour/Regulation of transcription/Gene expression

Background: Retinoids, rexinoids and their biologically active derivatives are involved in a complex arrangement of physiological and developmental responses in many tissues of higher vertebrates. Both retinoids and rexinoids are either natural or synthetic compounds related to retinoic acids that act through interaction with two basic types of nuclear receptors belonging to the nuclear receptor superfamily: All-trans retinoic acid receptors (RAR $\alpha$, RAR $\beta$, and $\mathrm{RAR} \gamma)$ and retinoid $\mathrm{X}$ receptors ( $\mathrm{RXR} \alpha, \mathrm{RXR} \beta$ and $\mathrm{RXR} \gamma)$ as retinoid-inducible transcription factors.

Aim: Summarization of selected effects of biologically active natural or synthetic retinoids and rexinoids and their exploitation in chemoprevention of various types of cancer.

Results: Retinoid receptors play a role as ligand-activated, DNA-binding, trans-acting, transcription-modulating proteins involved in a general molecular mechanism responsible for transcriptional responses in target genes. They exert both beneficial and detrimental activity; they have tumour-suppressive activity but on the other hand they are teratogenic. A number of nuclear receptor selective retinoids and rexinoids, have been successfully tested using a variety of cell lines or animal models. Retinoids inhibit carcinogenesis, suppress premalignant epithelial lesions and tumour growth and invasion in a variety of tissues.

Concusions: Natural and synthetic retinoids exert important biological effects due to their antiproliferative and apoptosis-inducing effects. They are also known to cause redifferentiation or to prevent further dedifferentiation of various tumour tissues.

\section{INTRODUCTION}

Retinoids and their natural metabolites and synthetic derivatives are polyisoprenoid compounds containing a cyclohexenyl ring. Their parent compound is all-trans retinol (vitamin A) and its subsequent oxidation product is all-trans retinal (retinaldehyde). From retinaldehyde alltrans retinoic acid (ATRA) is formed irreversibly ${ }^{1}$. ATRA is considered to be the main biologically active form of vitamin $\mathrm{A}$ in a variety of functions in vertebrates. 9-cis retinoic acid (9cRA) has a different spectrum of biological activity in comparison with that of all-trans retinoic acid. 9cRA is a high affinity ligand for the 9-cis retinoic acid (retinoid X or rexinoid) receptors (RXRs), as well as the all-trans retinoic acid receptors (RARs) ${ }^{2}$. Retinoids are involved in the complex arrangements of physiological and developmental responses in many tissues of higher vertebrates that include embryonic development, vision, reproduction, bone formation, haematopoiesis, metabolism, growth and differentiation of a variety of cell types, apoptosis and processes of carcinogenesis ${ }^{1-3}$. It is well known that retinoids are also teratogens and the therapeutic doses of them are contraindicated during pregnancy ${ }^{4}$. This article summarizes selected effects of biologically active natural or synthetic retinoids and rexinoids, acting through their cognate nuclear receptors, and their use in chemotherapy and chemoprevention of various types of cancer. We would like to apologize to all authors whose original references have not been mentioned in this article due to our intention to limit the references to a reasonable number.

\section{NUCLEAR RECEPTORS - LIGAND INDUCIBLE TRANSCRIPTION FACTORS}

A breakthrough in the field of nuclear receptors was discovery of the nuclear receptor superfamily that comprises nuclear receptors for steroid hormones, retinoids, thyroid hormones, vitamin $\mathrm{D}_{3}$, nuclear receptors for other biologically important compounds, and a number of "orphan" nuclear receptors for which the ligands remain still unknown ${ }^{5}$. It is generally accepted that nuclear receptors represent a superfamily of ligand-inducible transcription factors. Dysfunction of nuclear receptor signalling leads to proliferative, reproductive and metabolic diseases. The nuclear receptor superfamily of 48 identified nuclear receptors in human ${ }^{6}$ is shown in Table 1 and 2.

Proteins of the nuclear receptor superfamily represent single polypeptide chains with several major domains 
Table 1. Biologically active ligands and human nuclear receptors.

\begin{tabular}{|c|c|}
\hline Receptor (Abbreviation) & Ligand \\
\hline Thyroid hormone receptor $\alpha(\mathrm{TR} \alpha)$ & Thyroid hormone \\
\hline Thyroid hormone receptor $\beta(\operatorname{TR} \beta)$ & Thyroid hormone \\
\hline All-trans retinoic acid receptor $\alpha(\mathrm{RAR} \alpha)$ & $\begin{array}{l}\text { All-trans retinoic acid, } \\
\text { 9-cis retinoic acid, retinoids }\end{array}$ \\
\hline All-trans retinoic acid receptor $\beta$ (RAR $\beta)$ & All-trans retinoic acid, \\
\hline All-trans retinoic acid receptor $\gamma(\mathrm{RAR} \gamma)$ & $\begin{array}{l}\text { 9-cis retinoic acid, retinoids } \\
\text { All-trans retinoic acid, } \\
\text { 9-cis retinoic acid, retinoids }\end{array}$ \\
\hline 9-cis retinoic acid receptor $\alpha(\mathrm{RXR} \alpha)$ & 9-cis retinoic acid, rexinoids \\
\hline 9-cis retinoic acid receptor $\beta(\mathrm{RXR} \beta)$ & 9-cis retinoic acid, rexinoids \\
\hline 9-cis retinoic acid receptor $\gamma(\mathrm{RXR} \gamma)$ & 9-cis retinoic acid, rexinoids \\
\hline Vitamin $\mathrm{D}_{3}$ receptor (VDR) & Calcitriol \\
\hline Peroxisome proliferators-activated receptor $\alpha$ (PPAR $\alpha)$ & Fatty acids, fibrates, leukotriene B4 \\
\hline Peroxisome proliferators-activated receptor $\beta$ (PPAR $\beta)$ & Fatty acids \\
\hline Peroxisome proliferators-activated receptor $\gamma(\operatorname{PPAR} \gamma)$ & Fatty acids, thiazolidinediones \\
\hline Retinoid-related orphan receptor $\alpha(\operatorname{ROR} \alpha)$ & Cholesterol, cholesteryl sulphate \\
\hline Retinoid-related orphan receptor $\beta(\operatorname{ROR} \beta)$ & Retinoic acid \\
\hline Retinoid-related orphan receptor $\gamma(\operatorname{ROR} \gamma)$ & Retinoic acid \\
\hline Liver $\mathrm{X}$ receptor $\alpha(\mathrm{LXR} \alpha)$ & Oxysterols \\
\hline Liver $\mathrm{X}$ receptor $\beta(\mathrm{LXR} \beta)$ & Oxysterols \\
\hline Farnesoid X receptor $\alpha(\mathrm{FXR} \alpha)$ & Bile acids, fexaramine \\
\hline Pregnan $\mathrm{X}$ receptor $(\mathrm{PXR})$ & Xenobiotics \\
\hline Constitutive androstane receptor (CAR) & Xenobiotics, phenobarbital \\
\hline Estrogen receptor $\alpha(\mathrm{ER} \alpha)$ & Estradiol-17 $\beta$, tamoxifen \\
\hline Estrogen receptor $\beta(\mathrm{ER} \beta)$ & Estradiol-17 $\beta$ \\
\hline Estrogen receptor-related receptor $\beta$ (ERR $\beta)$ & 4-OH tamoxifen \\
\hline Estrogen receptor-related receptor $\gamma(\mathrm{ERR} \gamma)$ & 4-OH tamoxifen \\
\hline Glucocorticoid receptor (GR) & Cortisol, dexamethasone, RU486 \\
\hline Mineralocorticoid receptor (MR) & Aldosterone, spirolactone \\
\hline Progesterone receptor (PR) & Progesterone, RU486 \\
\hline Androgen receptor (AR) & Testosterone, flutamide \\
\hline
\end{tabular}

(Fig. 1). The amino terminal A/B-domain of the nuclear receptor molecule contains a constitutive activation function independent on ligand (AF-1). The central C-domain is a cysteine-rich DNA-binding region consisting of two highly conserved zinc fingers. The D-domain represents a highly flexible structure, and it plays a role as a hinge of the receptor molecule. The carboxy-terminal E-domain is responsible for the ligand binding, dimerization, and it contains inducible transactivation function dependent on ligand (AF-2) (ref. $\left.{ }^{7-9}\right)$.

All nuclear receptors are known to modulate gene transcription, although among them marked differences do exist, predominantly in the mechanisms through which it is accomplished ${ }^{10-12}$. 
Table 2. Human nuclear orphan receptors.

\begin{tabular}{|l|l|}
\hline Receptor & \\
\hline Reverse erbA $\alpha$ & Rev-erbA $\alpha$ \\
Reverse erbA $\beta$ & Rev-erbA $\beta$ \\
Human nuclear factor $4 \alpha$ & HNF4 $\alpha$ \\
Human nuclear factor $4 \gamma$ & HNF4 $\gamma$ \\
Testis receptor 2 & TR2 \\
Testis receptor 4 & TR4 \\
Tailless & TLL \\
Photoreceptor-specific nuclear receptor & PNR \\
Chicken ovalbumin upstream promoter-transcription factor I & COUP-TFI \\
Chicken ovalbumin upstream promoter-transcription factor II & COUP-TFII \\
ErbA2-related gene-2 & EAR2 \\
Estrogen receptor-related receptor $\alpha$ & ERR $\alpha$ \\
NGF-induced factor B & NGFIB \\
Nur-related factor 1 & NURR1 \\
Neuron-derived orphan receptor 1 & NOR1 \\
Steroidogenic factor 1 & SF1 \\
Liver receptor homologous protein 1 & LRH1 \\
Germ cell nuclear factor & GCNF \\
DSS-AHC critical region on the chromosome, gene 1 & DAX1 \\
Short heterodimeric partner & SHP \\
\hline
\end{tabular}

\section{All-trans and 9-cis retinoic acid receptors retinoic acid receptors}

The diversity of retinoic acid-induced signalling pathway is associated with existence of at least three subtypes for $\operatorname{RAR}(\alpha, \beta$ and $\gamma$ ) and three subtypes for $\operatorname{RXR}(\alpha$, $\beta$ and $\gamma$ ) with distinct amino- and carboxy-terminal domains. Later on, two major isoforms for RAR $\alpha(\alpha 1$ and $\alpha 2)$ and for RAR $\gamma(\gamma 1$ and $\gamma 2)$ and four major isoforms for $\operatorname{RAR} \beta$ ( $\beta 1, \beta 2, \beta 3$ and $\beta 4$ ) have been found. Similarly,

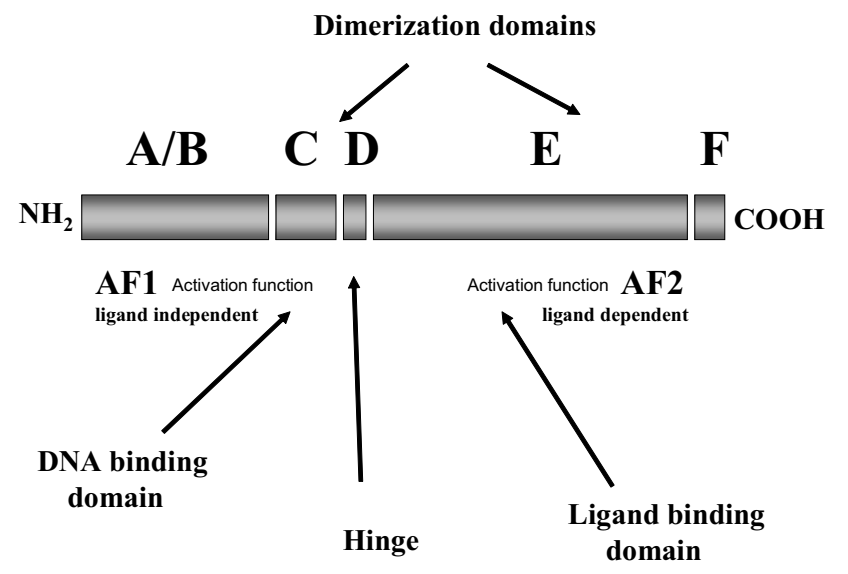

Fig. 1. Structural and functional organization of nuclear receptor specific domains two major isoforms for $\operatorname{RXR} \alpha(\alpha 1$ and $\alpha 2), \operatorname{RXR} \beta(\beta 1$ and $\beta 2$ ), and $\operatorname{RXR} \gamma(\gamma 1$ and $\gamma 2)$ have been identified up to now ${ }^{5,13}$. All-trans retinoic acid receptors upon all-trans retinoic acid binding act as all-trans retinoic acid-inducible transcription factors by directly interacting as heterodimers with 9-cis retinoic acid receptor. The RXR/RAR heterodimer interacts with specific DNA response elements of target genes and its effect on transcription is mediated also through recruitment of a number of coregulators

\begin{tabular}{llcccc}
\hline DIRECT REPEATS & TR & RAR & RXR & VDR \\
\hline DR+1 & AGGTCANAGGTCA & & & +++ & \\
DR+2 & AGGTCANNAGGTCA & & +++ & & \\
DR+3 & AGGTCANNNAGGTCA & & & & +++ \\
DR+4 & AGGTCANNNAGGTCA & +++ & & & \\
DR+5 & AGGTCANNNNAGGTCA & & +++ & & \\
\hline
\end{tabular}

Fig. 2. RXR/RAR heterodimers binding to specific DNA sequence - retinoic acid response elements (RAREs), characterized by direct repeats of two hexamers AGGTCA separated predominantly by five nucleotides $(\mathrm{DR}+5)$ or two nucleotides $(\mathrm{DR}+2)$ 
<smiles>CC1=C(/C=C/C(C)=C/C=C/C(C)=C/C(=O)O)C(C)(C)CCC1</smiles><smiles>CC1=C(/C=C/C(C)=C\C=C\C(C)=C\C(=O)O)C(C)(C)CCC1</smiles><smiles>CC1=C(/C=C/C(C)=C/C=C/C(C)=C/C(=O)Nc2ccc(O)cc2)C(C)(C)CCC1</smiles><smiles>C=C(c1ccc(C(=O)O)cc1)c1cc2c(cc1C)C(C)(C)CCC2(C)C</smiles>

7
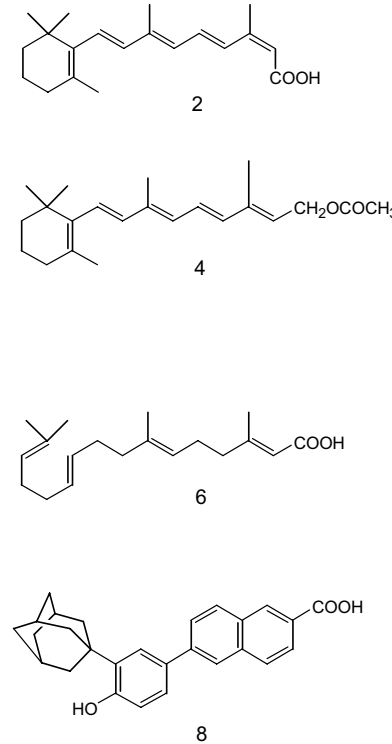

1. All-trans retinoic acid (TRETINOIN, VASANOID)

2. 13-cis retinoic acid (ISOTRETINOIN, ROACCUTANE)

3. 9-cis retinoic acid (ALITRETINOIN)

4. Retinyl acetate

5. N-(4hydroxyphenyl)retinamide (FENRETIDINE)

6. All-trans-3,7,11,15-tetramethyl-2,4,6, 10,14-hexadecapentanoic acid (NIK 333, Acyclic retinoid)

7. 4-[1-(5,6,7,8-tetrahydro-3,5, 5,8,8pentamethyl-2-naphtalenyl)ethenyl] benzoic acid (LGD1069, TARGRETIN, BEXAROTENE)

8. 6-[3-(1-adamantyl)-4-hydroxyphenyl]2-naphtalene carboxylic acid (AHPN, CD437)

Fig. 3. Chemical structure of selected retinoids and rexinoids

(corepressors and coactivators) $)^{5,10,11}$. Ligand occupancy of both receptors in RXR/RAR heterodimes was found to synergistically increase transcriptional activity ${ }^{14,15}$. RARs bind both all-trans retinoic acid and 9-cis retinoic acid with similar affinities while RXRs bind only 9-cis-retinoic acid. RXR/RAR heterodimers bind to specific DNA sequence - retinoic acid response elements (RAREs), characterized by direct repeats of two hexamers AGGTCA separated predominantly by two nucleotides $(\mathrm{DR}+2)$ or five nucleotides (DR+5) (Fig. 2). In the absence of all-trans retinoic acid, the RAR/RXR heterodimer recruits nuclear receptor corepressor proteins, e.g. nuclear receptor corepressor (N-CoR) or silencing mediator of retinoid and thyroid hormone receptor (SMRT), and associated enzymes such as histone deacetylases or DNA-methyl transferases that lead to an inactive condensed chromatin structure preventing transcription process. All-trans retinoic acid binding leads to the dissociation of corepressor proteins and enables association of coactivator proteins (histone acetyltransferases or histone arginine methyltransferases) with liganded receptor complex yielding in activation of gene transcription ${ }^{6,16-18}$. Thus, the retinoid receptors are considered to be ligand-activated, DNA-binding, trans-acting, transcription-modulating nuclear proteins involved in a general molecular mechanism responsible for transcriptional responses in target genes ${ }^{6}$.

The retinoids selective for specific binding to RXRs are called rexinoids ${ }^{19}$, and RXRs play an crucial role in the nuclear receptor mediated transcription processes for their ability to heterodimerize with many other members of nuclear receptor superfamily, including RARs, thyroid hormone receptors (TRs), vitamin $\mathrm{D}_{3}$ receptor (VDR), peroxisome proliferator-activated receptors (PPARs), liver $X$ receptors (LXRs), farnesoid $X$ receptor (FXR), pregnan $\mathrm{X}$ receptor (PXR), and constitutively activated receptors
(CARs) (ref. ${ }^{6,20,21}$ ). RXRs thus behave as promiscuous dimerization partners for a large number of nuclear receptors, and thus play an integrative and crucial role in nuclear receptor mediated pathways ${ }^{6,22,23}$. While RAR ligand (agonist) autonomously activates transcription through RXR/RAR heterodimer, RXRs are unable to respond to RXR ligands (rexinoids) in the absence of RAR ligand. Rexinoid binding to RXR is incapable to induce the dissociation of corepressor molecule from the RXR/ RAR heterodimers ${ }^{24}$ moreover, no interaction was found between RXRs and corepressors NCoR and SMRT ${ }^{25}$.

Genetic strategies in the mouse in order to determine the function of both RAR and RXR subtypes have shown following results. RAR $\alpha$ null mutant males have been found to be sterile due to degeneration of the seminiferous epithelium causing inhibition of spermatogenesis ${ }^{26-28}$, RAR $\beta$ null mice display abnormalities in the vitreous body in eyes and impaired abilities in locomotion and motor coordination, and ablation of RAR $\gamma$ causes both skeletal and epithelial defects ${ }^{29}$. The loss of RXR $\alpha$ was found to be lethal during fetal life due to hypoplasia of the myocardium that appears to be the principal cause of animal death. Moreover, fetuses lacking RXR $\alpha$ have ocular malformation. Also, it has been shown that $\mathrm{RXR} \alpha$ is involved in the mediation of a teratogenic effect due to administration of exogenous retinoids $\mathrm{s}^{30-32}$. The ablation of RXR $\beta$ led to approximately $50 \%$ in utero lethality. Males lacking RXR $\beta$ are sterile and exhibit testicular defects and abnormal spermatid maturation, leading to defects of spermatozoa. Moreover, RXR $\beta$ mutation causes abnormal lipid metabolism in Sertoli cells, suggesting functional interactions of RXR $\beta$ with other nuclear receptors that control lipid metablism ${ }^{32-34}$. RXR $y$ null mutants are fertile but they have higher serum levels of both L-thyroxine and thyroid-stimulating hormone (TSH), and increased metabolic rate when compared to wild type animals ${ }^{32,35}$. 
Thus, RXR-RAR heterodimers play an important role in transducing in vivo the retinoid signal and that specific heterodimers are involved in many developmental and metabolic processes $^{28,32}$.

\section{RETINOID SIGNALLING IN CHEMOPREVENTION OF SELECTED MALIGNANT DISEASES}

In animal models, retinoids or rexinoids have been found to suppress carcinogenesis or induce differentiation of malignant cells through their cognate nuclear receptors in a variety of tissues ${ }^{36}$. Altered expression of all-trans or 9cis retinoic acid receptors may be associated with the processes of malignant transformation of animal or human cells in a variety of tissues. Aberrant retinoid signalling mechanisms is oftentimes linked to cancer, and at present, the retinoids are used to a progressively increasing extent in a variety of chemopreventive and chemotherapeutic settings ${ }^{28}$.

\section{Acute promyelocytic leukaemia and exploitation of retinoids}

The most direct implication of RAR in human disease is given by acute promyelocytic leukaemia (APL), which is characterized by selected expansion of immature myeloid precursors or malignant myeloid cells blocked at the promyelocytic stage of hemopoietic development ${ }^{36,37}$. Retinoic acids as retinoid inducible transcription factors are involved in myeloid differentiation through nuclear receptor heterodimer (RXR/RAR $\alpha$ ) to modulate the expression of target genes. Molecular studies have identified the fusion of the RAR $\alpha$ gene to partner genes as the crucial event in APL pathogenesis ${ }^{38-40}$. APL has been found to be associated with reciprocal translocation involving the RAR $\alpha$ gene on chromosome 17 that translocates and fuses to genes including promyeolocytic leukemia gene (PML), promyelocytic leukemia zinc finger gene, nucleophosmin gene, nuclear mitotic apparatus gene, and the Stat5b gene ${ }^{3,37,41}$. RAR $\alpha$ usually fuses to the PML gene on chromosome 15 yielding the PML - RAR $\alpha$ chimeric gene, which is expressed in all APL patients with $\mathrm{t}(15 ; 17)^{39,42}$. Thus, chimeric receptors are responsible for development of leukemias by interfering with the functions of RARs, RXRs and PML expressed by the normal alleles present in the same cell ${ }^{41}$. In addition, it has been shown that PML - RAR $\alpha$ is capable to form homodimer through the coiledcoil motif of PML and thus to compete with the RAR $\alpha$ for binding to retinoic acid responsive element of target genes $^{39}$. The all-trans retinoic acid-induced differentiation of cells is based on important findings that it can cause a degradation of PML - RAR $\alpha$, induce dissociation of corepressors from PML - RAR $\alpha^{37}$. All-trans retinoic acid (ATRA) effects are also accompanied by cell cycle arrest at G1 phase and inhibition of cell growth. Results based on in vitro studies enabled the treatment of APL patients with all-trans retinoic acid that caused the malignant cells to differentiate towards mature granulocytes, thus regaining most functions of their normal counterparts ${ }^{39}$. In the meantime, ATRA (Tretinoin, Vasanoid) was approved by the FDA for differentiation therapy of patients with acute promyelocytic leukemia and the successful application of all-trans retinoic acid for treatment of APL might be considered as a start of the retinoid renaissance period, since it rekindled interest in the use of retinoids or rexinoids for treatment of a variety of established malignancies. In addition, high concentration of ATRA is able to induce postmaturation apoptosis through the induction of the tumour-selective death ligand tumour necrosis factor-related apoptosis-inducing ligand TRAIL, also called Apo2L, a most promising molecule in cancer research ${ }^{28,43,44}$.

\section{Retinoids or rexinoids in breast cancer chemoprevention}

Breast cancer incidence, morbidity and mortality remain a major problem in the most of countries. Breast cancer development is associated with deregulation of cell growth and cell death. It has been shown that retinoids are able to inhibit mammary gland cancer in animal models and human breast cancer ${ }^{36,45-47}$. They are effective inhibitors of breast cancer cells at the early stages of tumour progression and their effectiveness diminishes as tumours become more aggressive ${ }^{48}$. Retinoid receptors are expressed differently in normal and malignant epithelial cells and are critical for normal development ${ }^{49}$. Recently, we have also shown marked differences between nonlactating and postlactating mammary gland in rat. RAR $\alpha$, $\mathrm{RXR} \alpha \mathrm{N}-\mathrm{CoR}, \mathrm{SMRT}$ in rat were significantly increased in postlactating mammary gland when compared to that of nonlactating mammary tissue. Postlactating mammary glands were found to express all RAR and RXR subtypes studied when compared to nonlactating mammary tissues that express exclusively RAR $\alpha$ and RXR $\alpha$ subtypes. Enhanced expression of a number of nuclear hormone receptors, their coregulators in mammary tissue of postlactating rats in comparison with nonlactating animals identify a potential role for retinoid signalling pathways also after lactation period ${ }^{50}$. Growth inhibition of breast cancer cells by retinoic acid has been associated with induction of the expression of RAR $\beta$, which may act as a tumour suppressor and appears to be down-regulated in breast cancer tissue and cell lines, and conversely, up regulated in normal mammary epithelian cells $\mathrm{s}^{51}$. 9-cis retinoic acid, a high affinity ligand for RXRs as well as LGD1069 (Targretin, Bexarotene) (Fig. 3), a synthetic RXR-selective ligand have been shown to have efficacy superior to ATRA as a chemopreventive compound in the 1-methyl-1-nitrosourea (MNU)-induced rat mammary gland carcinoma model. Moreover, Targretin was very well tolerated during chronic therapy with no classic signs of "retinoid-associated" toxicities ${ }^{52}$. In animal mammary gland carcinoma models, additional promising retinoids are retinyl acetate or N-(4-hydroxyphenyl)retinamide (Fenretinide) ${ }^{53}$ (Fig. 3). As mentioned before, lack of RAR $\beta$ gene expression is a typical feature for human breast cancer and may be one of the major factors responsible for retinoid resistance in those neoplasias. Examination of the expression of all the subtypes of RARs and RXRs in a number of hormonedependent and hormone-independent breast cancer cells 
have shown similar expression of RAR $\alpha, \operatorname{RAR} \gamma, \mathrm{RXR} \alpha$ and RXR $\beta$. However, all-trans retinoic acid was found to be a strong inductor of the RAR $\beta$ gene expression in several hormone-dependent breast cancer cell lines. Due to up-regulation of RAR $\beta$ by all-trans retinoic acid or other retinoids, the expression of RAR $\beta$ apparently plays a critical role in increasing retinoid sensitivity. These data indicate that the deficiency of the RAR $\beta$ expression and a deficient responsiveness of retinoids via RAR $\beta$ may account for the ineffective treatment with retinoids in patients with advanced breast tumour ${ }^{51}$. The potency of retinoids to inhibit proliferation of breast cancer cells was seen when retinoids were administered either alone or in combination with antiestrogens. Tamoxifen and fenretinide combination therapy has been proven to be an active treatment regimen in metastatic breast cancer patients, however, not in estrogen receptor negative metastatic breast cancer or in patients whose disease had progressed on tamoxifen ${ }^{54}$. Retinoids do not require estrogen receptors for their action, they may affect neoplastic transformation in estrogen-negative cells, in contrast to tamoxifen, whose primary mechanism of action is through estrogen receptors. In spite of that, retinoids and rexinoids seem to be more active in estrogen positive than in estrogen negative precancerous tissue $e^{55}$. Furthermore, it is known that retinoids can promote apoptosis in breast cancer cells as well as in other types of neoplasias and that induction is predominantly mediated by RAR $\beta^{56}$. In spite of a number of important findings achieved recently by many prestigious laboratories, the precise mechanism(s) by which natural or synthetic retinoids inhibit breast cancer cell growth has not been completely elucidated. Great interest has been recently focused on rexinoids, when combined with selective estrogen receptor modulators (SERMs), they dramatically inhibit breast cancer cell growth inducing apoptosis even with intermittent administration ${ }^{49}$.

\section{Retinoids in thyroid gland cancer treatment}

Thyroid cancer is a relatively common malignancy. A minority of patients suffers from poorly differentiated thyroid carcinoma that is unresponsive to radioiodine therapy. Redifferentiation agents that "reprogram" these thyroid tumours in order to concentrate radioiodine would be of great value in treating patients with advanced thyroid cancer ${ }^{57-59}$. The biologically active retinoids or rexinoids are extensively studied from that aspect. In follicular thyroid cancer cells, 13-cis retinoic acid has been found to induce radioiodine avidity of cells formerly unable to accumulate radioiodine ${ }^{60}$. In human thyroid carcinoma cell lines, natural or synthetic retinoids were found to induce expression of type I iodothyronine-5'-deiodinase, sodium/ iodide-symporter, the thyroid differentiation markers ${ }^{61-63}$. However, approximately $30 \%$ of the thyroid tumors may start to dedifferentiate and thus finally develop into highly malignant anaplastic thyroid carcinomas ${ }^{64}$. Non-operable thyroid follicular tumors, which due to loss of thyroid specific functions also fail to take up radioiodine, have been treated with 13-cis retinoic acid. The beneficial outcome of this treatment was interpreted as partial redifferentiation of thyroid cancer cells ${ }^{64}$. This effect markedly requires existence of functional nuclear retinoid/rexinoid receptors. The presence of high-affinity and limited capacity of nuclear all-trans retinoic acid binding sites has been shown in follicular thyroid carcinoma cell lines ${ }^{65}$. The ability of retinoid receptors in thyroid carcinoma cell lines to bind to their responsive elements has been evaluated by electrophoretic mobility and supershift assays ${ }^{66}$. In clinical pilot studies patients with poorly differentiated, inoperable thyroid carcinoma and lacking or insufficient iodine uptake have been treated with oral doses of $1.0-1.5 \mathrm{mg}$ 13-cis retinoic acid per $\mathrm{kg}$ body weight and day over 5 weeks. The results revealed an increased radioiodide uptake in $30 \%-50 \%$ of patients ${ }^{64}$. In a recent study a fluorine-18 fluorodeoxyglucose positron emission tomography $\left({ }^{18} \mathrm{~F}\right.$-FDG PET) was used for the evaluation and monitoring of therapy with 13-cis retinoic acid in thyroid cancer. In 6 out of 21 patients, radioiodine accumulation was newly induced after 6-9 months, and in 3 patients a residual iodine accumulation was enhanced ${ }^{67}$. The data correspond well with findings described previously indicating retinoids as promising therapeutic agents for the treatment of thyroid cancer ${ }^{59}$.

\section{Possible use of retinoids or rexinoids in other organs cancer chemoprevention}

Retinoids as previously reviewed ${ }^{36}$ have been implicated in induction of cell death in many tumour-derived cultured cell systems or tumour tissues, e.g., neuroblastoma cells, ovarian cancer, cervical cancer cells, prostate cancer, head and neck squamous cell carcinoma, liver cancer, pancreatic cancer, lung cancer and many other types of carcinomas. Relationship between biologically active retinoids or rexinoids, which can act as effective cancer chemopreventive agents or potential chemotherapeutic compounds and the regulation of the processes such as cell differentiation and apoptosis is very complex and requires identification of new target genes that might be involved in those processes.

\section{CONCLUSION}

A variety of biologically active retinoids or rexinoids has been tested on different types of cancer in order to evaluate the precise mechanism of action. In a number of different types of tumours both retinoids or rexinoids are capable to induce both apoptosis and differentiation, and they represent a potentially powerful alternative to present chemotherapeutic treatment of late stages of cancer ${ }^{36}$.

In conclusion, a number of novel chemical compounds, receptor selective retinoids and rexinoids, have been synthesized up to now and tested both in vitro and in vivo. In spite of that rapid progress novel synthetic retinoids and rexinoids with greater retinoid receptor selectivity, reduced teratogenic and other side effects are still highly required. 


\section{ACKNOWLEDGEMENTS}

This work was supported by the grant of VEGA No. 2/5017/5 and the $6^{\text {th }}$ Framework Programme EU, Network of Excellence Project EU (CASCADE), FOOD-CT-2004506319

\section{REFERENCES}

1. DeLuca LM. Retinoids and their receptors in differentiation, embryogenesis and neoplasia. FASEB J 1991; 5:2924-33.

2. Lotan R. Retinoids and apoptosis: Implication for cancer chemoprevention and therapy. J Natl Cancer Inst 1995; 87:1655-7.

3. Sun S-Y, Lotan R. Retinoids as chemopreventive and therapeutic agents. Drugs Fut 1998; 23:621-34.

4. Hinds TS, West WL, Knight EM. Carotenoids and retinoids: a review of research, clinical, and public health application. J Clin Pharmacol 1997; 37:551-8.

5. Chambon P. A decade of molecular biology of retinoic acid receptors. FASEB J 1996; 10:940-5.

6. Germain P, Staels B, Dacquet C, Spedding M, Laudet V. Overview of nomenclature of nuclear receptors. Pharmacol Rev 2006 58:685-704

7. Nagpal S, Friant S, Nakshatri H, Chambon P. RARs and RXRs: Evidence for two autonomous transactivation functions (AF-1 and AF-2) and heterodimerization in vivo. EMBO J 1993; 12:234960.

8. Mader S, Leroy P, Chen JY, Chambon P. Multiple parameters control the selectivity of nuclear receptors for their response elements. J Biol Chem 1993; 268:591-600.

9. Durand B, Saunders M, Gaudon C, Roy B, Losson R, Chambon P. Activation function (AF-2) of retinoic acid receptor and 9-cis retinoic acid receptor: presence of a conserved autonomous constitutively activating domain and influence of the nature of the response element. EMBO J 1994; 13:5370-82.

10. Mangelsdorf DJ, Thummel C, Beato M, Herrlich P, Schutz G, Umesono K, Blumberg B, Kastner P, Mark M, Chambon P, Evans RM. The nuclear receptor superfamily: the second decade. Cell 1995; 85:835-9.

11. Aranda A, Pascual A. Nuclear hormone receptors and gene expression. Physiol Rev 2001; 81:1269-304.

12. Bain DL, Heneghan AF, Connaghan-Jones KD, Miura MT. Nuclear receptor structure: implications for function. Ann Rev Physio 2006; 69:201-20.

13. Sun S-Y, Lotan R. Retinoids and their receptors in cancer development and chemoprevention. Crit Rev Oncol Hematol 2002; 41:41-55.

14. Minucci S, Leid M, Toyama R, Saint-Jeannet JP, Peterson VJ, Horn V, Ishmael JE, Bhattacharyya N, Dey A, Dawid IB, Ozato $\mathrm{K}$. Retinoid X receptor (RXR) within the RXR-retinoic acid receptor heterodimer binds its ligand and enhances retinoid dependent gene expression. Mol Cell Biol 1997; 17:644-655.

15. Crowe DL. Receptor selective synthetic retinoids as potential cancer chemotherapy agents. Curr Cancer Drug Targets 2002; 2:77-86.

16. Freedman, LP. Increasing the complexity of coactivation in nuclear receptor signaling. Cell 1999; 97:5-8.

17. Privalsky ML. Regulation of SMRT and N-CoR corepressor function. Curr Top Microbiol Immunol 2001; 254:117-36.

18. Perissi V, Rosenfeld MG. Controlling nuclear receptors: the circular logic of cofactor cycles. Nat Rev Mol Cell Biol 2005; 6:542-54.

19. Mukherjee R, Davies PJ, Crombie DL, Bischoff ED, Cesario RM, Jow L, Hamann LG, Boehm MF, Mondon CE, Nadzan AM, Paterniti JR Jr, Heyman RA. Sensitization of diabetic and obese mice to insulin by retinoid X receptor agonists. Nature 1997; 386:407-10.

20. Mangelsdorf DJ, Evans RM. The RXR heterodimers and orphan receptors. Cell 1995; 83:841-50.
21. Willy PJ, Mangelsdorf DJ. Nuclear orphan receptors: the search for novel ligands and signaling pathways. Horm Signal 1998; 1:307358.

22. Benoit G, Altucci L, Flexor M, Ruchaud S, Lillehaug J, Raffelsberger W, Gronemeyer H, Lanotte M. RAR-independent RXR signaling induces $\mathrm{t}(15 ; 17)$ leukemia cell maturation. EMBO J 1999; 18:7011-7018.

23. Sporn MB, Suh N. Chemoprevention of cancer. Carcinogenesis 2000; $21: 525-530$

24. Germain P, Iyer J, Zechel C, Gronemeyer H. Coregulator recruitment and the mechanism of retinoic acid synergy. Nature 2002; 415:187-92.

25. Zhang J, Zamir I, Lazar MA. Differential recognition of liganded and unliganded thyroid hormone receptor by retinoid $\mathrm{X}$ receptor regulates transcriptional repression. Mol Cell Biol 1997; 17:688797.

26. Li E, Sucov HM, Lee KF, Evans RM, Jaenisch R. Normal development and growth of mice carrying a targeted disruption of the alpha 1 retinoic acid receptor gene. Proc Natl Acad Sci USA 1993; 90:1590-4

27. Lufkin T, Lohnes D, Mark M, Dierich A, Gorry P, Gaub MP, LeMeur M, Chambon P. High postnatal lethality and testis degeneration in retinoic acid receptor alpha mutant mice. Proc Natl Acad Sci USA 1993; 90:7225-9.

28. Germain P, Chambon P, Eichele G, Evans RM, Lazar MA, Leid M, De Lera AR, Lotan R, Mangelsdorf DJ, Gronemeyer H. International Union of Pharmacology. LX. Retinoic acid receptors. Pharmacol Rev 2006; 58:712-25.

29. Chapellier B, Mark M, Messaddeq N, Calleja C, Warot X, Brocard J, Gerard C, Li M, Metzger D, Ghyselinck NB, Chambon P. Physiological and retinoid-induced proliferations of epidermis basal keratinocytes are differently controlled. EMBO J 2002; 21:3402-13.

30. Kastner P, Grondona JM, Mark M, Gansmuller A, LeMeur M, Decimo D, Vonsech JL, Dolle P, Chambon P. Genetic analysis of RXR alpha developmental function: convergence of RXR and RAR signaling pathways in heart and eye morphogenesis. Cell 1994; 78:987-1003

31. Sucov HM, Dyson E, Gumeringer CL, Price J, Chien KR, Evans RM. RXR alpha mutant mice establish a genetic basis for vitamin A signaling in heart morphogenesis. Genes Dev 1994; 8:100718.

32. Germain P, Chambon P, Eichele G, Evans RM, Lazar MA, Leid M, De Lera AR, Lotan R, Mangelsdorf DJ, Gronemeyer H. International Union of Pharmacology. LXIII. Retinoid X receptors. Pharmacol Rev 2006; 58:782-97.

33. Kastner P, Mark M, Leid M, Gansmuler A, Chin W, Grondona JM, Decimo D, Krezel W, Dierich A, Chambon P. Abnormal spermatogenesis in RXR beta mutant mice. Genes Dev 1996; 10:80-92.

34. Mascrez B, Ghyselinck NB, Watanabe M, Annicotte JS, Chambon P, Auswerx J, Mark M. Ligand-dependent contribution of RXR beta to cholesterol homeostasis in Sertoli cells. EMBO Rep 2004; 5:285-90.

35. Brown NS, Smart A, Sharma V, Brinkmeier ML, Greenlee L, Camper SA, Jensen DR, Eckel RH Krezel W, Chambon P, Haugen BR. Thyroid hormone resistance and increased metabolic rate in the RXR-gamma-deficient mouse. J Clin Invest 2000; 106:73-9.

36. Brtko J, Thalhamer J. Renaissance of the biologically active vitamin A derivatives: Established and novel directed therapies for cancer and chemoprevention. Curr Pharm Design 2003; 9:2067-77.

37. Lin RJ, Egan DA, Evans RM. Molecular genetics of acute promyelocytic leukemia. Trends Genet 1999; 15:179-84.

38. Warrell RP Jr, de The H, Wang ZY, Degos L. Acute promyelocytic leukemia. N Engl J Med 1993; 329:177-89.

39. Zhang J-W, Gu J, Wang Z-Y, Chen S-J, Chen Z. Mechanisms of alltrans retinoic acid-induced differentiation of acute promyelocytic leukemia cells. J Biosci 2000; 25:275-84.

40. Chen Z, Tong JH, Dong S, Zhu J, Wang ZY, Chen SJ. Retinoic acid regulatory pathways, chromosomal translocations and acute promyelocytic leukemia. Genes Chromosomes Cancer 1996; 15:147-56. 
41. Melnick A, Licht JD. Deconstructing a disease: RAR alpha, its fusion partners, and their roles in the pathogenesis of acute promyelocytic leukemia. Blood 1999; 93:3167-215.

42. He LZ, Merghoub T, Pandolfi PP. In vivo analysis of the molecular pathogenesis of acute promyelocytic leukemia in the mouse and its therapeutic implications. Oncogene 1999; 18:5278-92.

43. Altucci L, Gronemeyer H. The promise of retinoids to fight against cancer. Nat Rev Cancer 2001; 1:181-93.

44. Fenaux P, Wang ZZ, Degos L. Treatment of acute promyelocytic leukemia by retinoids. Curr Top Microbiol Immunol 2007; 313:101-28.

45. Mehta RG. Experimental basis for the prevention of breast cancer. Eur J Cancer 2000; 36:1275-82.

46. Fontana JA, Mezu AB, Copper BN, Miranda D. Retinoid modulation of estradiol-stimulated growth and of protein synthesis and secretion in human breast carcinoma cells. Cancer Res 1990; 50:1997-2002.

47. Macejova D, Dvorcakova M, Weiss R, Scheiblhofer S, Mostbock S, Liska J, Szabova L, Zorad S, Thalhamer J, Brtko J. Reduction of 1-methyl-1-nitrosourea-insuced mammary gland carcinoma by in vivo application of immunostimulatory $\mathrm{CpG}$ motifs in SpragueDawley rats. Gen Physiol Biophys 2001; 20:445-8.

48. Brtko J. Role of retinoids and their cognate nuclear receptors in breast cancer chemoprevention. Cent Eur J Public Health 2007; $15: 3-6$.

49. Zanardi S, Serrano D, Argusti A, Barile M, Puntoni M, Decensi A. Clinical trials with retinoids for breast cancer chemoprevention. Endocrine-Related Cancer 2006; 13:51-68.

50. Macejova D, Baranova M, Liska J, Brtko J. Expression of nuclear hormone receptors, their coregulators and type I iodothyronine 5 '-deiodinase gene in mammary tissue of nonlactating and postlactating rats. Life Sci 2005; 77:2584-93.

51. Zhang X-K, Liu Y, Lee MO. Retinoid receptors in lung cancer and breast cancer. Mutation Research 1996; 350:267-77.

52. Gottardis MM, Bischoff ED, Shirley MA, Wagoner MA, Lamph WW, Heyman RA. Chemoprevention of mammary carcinoma by LGD1069 (Targretin): an RXR-selective ligand. Cancer Res 1996; 56:5566-70

53. Moon RC, Constantinou AI. Dietary retinoids and carotenoids in rodent models of mammary tumorigenesis. Breast Cancer Res Treat 1997; 46:181-9.

54. Zujewski J, Pai L, Wakefield L, Giusti R, Dorr FA, Flanders C, Caruso R, Kaiser M, Goodman L, Merino M, Gossard M, Noone
MA, Denicoff A, Venzon D, Cowan KH, O'Shaughnessy JA. Tamoxifen and fenretinide in women with metastatic breast cancer. Breast Cancer Res Treat 1999; 57:277-83.

55. Fabian CJ. Breast cancer chemoprevention: beyond tamoxifen. Breast Cancer Res 2001; 3:99-103.

56. Zhang X-K. Vitamin A and apoptosis in prostate cancer. Endo Related Cancer 2002; 9:87-102.

57. Haugen BR. Redifferentiation therapy in advanced thyroid cancer. Curr Drug Targets Immune Endocr Metabol Disord 2004; 4:175-80.

58. Schmutzler C. Regulation of the sodium/iodide symporter by retinoids - a review. Exp Clin Endocrinol Diabetes 2001; 109:41-4.

59. Schmutzler C, Köhrle J. Retinoic acid redifferentiation therapy for thyroid cancer. Thyroid 2000; 10:393-406.

60. Van Herle AJ, Agatep ML, Padua DN 3rd, Van Herle HML, Juillard, GJF. Effects of 13-cis retinoic acid on growth and differentiation of human follicular carcinoma cells (UCLA RO $82 \mathrm{~W}-1$ ) in vitro. J Clin Endocrinol Metab 1990; 71:755-63.

61. Schreck R, Schneiders F, Schmutzler C, Köhrle J. Retinoids stimulate type-I iodothyronine 5'-deiodinase activity in human follicular thyroid - carcinoma cell lines. J Clin Endocrinol Metab 1994; 79:791-8.

62. Schmutzler C, Winzer R, Meissner-Weigl J, Köhrle J. Retinoic acid increases sodium/iodide symporter mRNA levels in human thyroid cancer cell lines and suppresses expression of functional symporter in nontransformed FRTL-5 rat thyroid cells. Biochem Biophys Res Commun 1997; 240:832-8.

63. Schmutzler C, Schmitt TL, Glaser F, Loos U, Köhrle J. The promoter of the human sodium/iodide-symporter gene responds to retinoic acid. Mol Cell Endocrinol 2002; 189:145-55.

64. Schmutzler C, Köhrle J. Innovative strategies for treatment of thyroid cancer. Eur J Endocrinol 2000; 143:15-24.

65. Schmutzler C, Brtko J, Bienert K, Köhrle J. Effect of retinoids and role of retinoic acid receptors in human thyroid carcinomas and cell lines derived therefrom. Exp Clin Endocrinol Diabetes 1996; 104(Suppl. 4):16-9.

66. Schmutzler C, Brtko J, Winzer R, Jakobs TC, Meissner-Weigl J, Simon D, Goretzki PE, Köhrle J. Functional retinoid and thyroid hormone receptors in human thyroid-carcinoma cell lines and tissues. Int J Cancer 1998; 76:368-76.

67. Boerner AR, Petrich T, Weckesser E, Fricke H, Hofmann M, Otto D, Weckesser M, Langen KJ, Knapp WH. Monitoring isotretinoin therapy in thyroid cancer using 18F-FDG PET. Eur J Nucl Med 2002; 29:231-6. 